\title{
Metapopulation in bats of Southern Brazil
}

\author{
Reis, NR. ${ }^{a *}$, Fregonezi, MN. ${ }^{a}$, Peracchi, AL. ${ }^{b}$ and Rossaneis, BK. ${ }^{a}$ \\ aLaboratório de Ecologia de Mamíferos, Departamento de Biologia Animal e Vegetal, \\ Universidade Estadual de Londrina - UEL, PR 445, Km 389, CEP 86051-990, Londrina, PR, Brazil \\ 'Laboratório de Mastozoologia, Instituto de Biologia, Universidade Federal Rural do Rio de Janeiro - UFRRJ, \\ BR 465, Km 7, CEP 23890-000, Seropédica, RJ, Brazil \\ *e-mail: nrreis@uel.br
}

Received June 13, 2011 - Accepted September 8, 2011 - Distributed August 31, 2012

(With 2 figures)

\begin{abstract}
The purpose was to show that displacements, promoters of genetic diversity in metapopulations, increase the probability of survival of bat species adapted to medium and long-distance flights. Samples were taken in four forest fragments, distributed in three municipalities in northern Paraná, and the maximum distance between the studied areas is $20 \mathrm{~km}$. A monthly sampling was performed for each fragment, for the period of July 2008 to June 2009 . We used eight nets for collection which remained open during the first four hours of the night, totalling 192 hours during a year of study. The marking occurred from October 2008 to March 2009 and was accomplished through the use of anodised metal rings of four different colours. One hundred and fifty individuals were banded and since the first capture, four displacements were recorded. After five months of collecting and marking, one Carollia perspicillata was found three $\mathrm{km}$ away. Two Artibeus lituratus were recorded about $20 \mathrm{~km}$ from the marking place: the first one after 22 months and the second one after 24 months. Additionally, one Platyrrhinus lineatus was captured at about $20 \mathrm{~km}$, after 26 months. As they moved around over considerable distances and are not monogamous, they mate with females of other fragments, exchanging genes and reducing or even avoiding inbreeding. Thus, populations of bats have the ability to increase genetic diversity in metapopulations, provided by displacements between the forest fragments. Species that behave like this are not vulnerable to isolation.
\end{abstract}

Keywords: bats, displacements, gene flow, preservation.

\section{Metapopulação em morcegos do sul do Brasil}

\section{Resumo}

Objetivou-se mostrar que os deslocamentos, promotores da diversidade genética em metapopulações, incrementam a probabilidade de sobrevivência das populações de espécies de morcegos adaptadas para voos de média e longa distância. As amostragens foram realizadas em quatro fragmentos florestais, distribuídos em três municípios da região norte do Paraná, sendo que a distância máxima entre as áreas de estudo foi de $20 \mathrm{~km}$. Uma amostragem mensal foi realizada em cada fragmento, durante o período de julho de 2008 a junho de 2009. Foram utilizadas oito redes por coleta, que permaneceram abertas durante as quatro primeiras horas da noite, totalizando 192 horas, durante um ano de estudo. A marcação ocorreu de outubro de 2008 a março de 2009 e foi realizada por meio de anilhas metálicas anodizadas de quatro cores diferentes. Cento e cinquenta indivíduos foram marcados e, desde a captura, foram registrados quatro deslocamentos. Após cinco meses da coleta e da marcação, um Carollia perspicillata foi encontrado a três quilômetros. Dois Artibeus lituratus foram registrados a cerca de $20 \mathrm{~km}$ do local de marcação, um destes após 22 meses e o segundo, após 24 meses. Adicionalmente, um Platyrrhinus lineatus foi capturado a cerca de $20 \mathrm{~km}$, após 26 meses. Ao se locomoverem por razoáveis distâncias, como não são monogâmicos, os machos cruzam com fêmeas de outros fragmentos, trocando genes e reduzindo - ou mesmo evitando - a endogamia. Assim, há a possibilidade de se incrementar a diversidade genética nas metapopulações, possibilitada pelos deslocamentos entre os fragmentos. As espécies que assim se comportam não são vulneráveis ao isolamento.

Palavras-chave: quirópteros, deslocamentos, fluxo gênico, preservação. 


\section{Introduction}

A set of populations connected by individuals who move between them constitute a metapopulation (Ricklefs, 1993; Paglia et al., 2006), as well as a population of populations. Initially, the metapopulation theory was proposed by North American ecologist Levins (1970), shortly after the release of the theory of island biogeography (MacArthur and Wilson, 1967). Historically, one was already aware of long migratory shifts of species common in Brazil, as Tadarida brasiliensis (I. Geoffroy, 1824), flying over $1,000 \mathrm{~km}$, from the United States to Mexico, south or northbound, depending on climatic variables (temperature) and also the genus Myotis, which move more than $300 \mathrm{~km}$, between Alabama and Tennessee, south of North America (Fleming and Eby, 2003). It is known that in southeastern and southern Brazil, the fragmented landscape is surrounded by modified environments that may or may not be unfavourable for bat species. The matrix surrounding forest fragments may be used and re-populated by species with some adaptive potential and extinguish those "estenobiontes" (Primack, 1993), so the degree of utilization of areas between the fragments ranges widely, causing changes in the population dynamics of species.

The size of the populations that relate to each other and form metapopulations depends on the number of individuals, migration and power of colonisation of each species. The exchange of genes between bats that seek, colonise and forage large areas is a decisive factor for the maintenance of gene flow, which is necessary to prevent a greater incidence of deleterious alleles within populations, which protect the survival of species (Pires et al., 2003).
What is the main advantage in bats exchanging genes with other populations, through displacement, forming metapopulations? To avoid the loss of evolutionary flexibility that occurs due to reduced genetic variability, which induces the population to not respond positively to environmental variances, a fundamental process for evolutional adaption in environments that suffer disturbances (Stockwell et al., 2003; Begon et al., 2007).

It is important to emphasize that " $\mathrm{k}$ " strategists like bats, which have a long life and generate very few offspring, need mechanisms to protect their population and continue the survival of the species (Odum and Barrett, 2007).

The objective here is to show that displacements, promoters of genetic diversity in metapopulations, increase the probability of survival of bat species adapted to medium and long-distance flights.

\section{Material and Methods}

\subsection{Study area}

Samples were taken in four forest fragments, distributed in three municipalities of northern Paraná: Sitio Cazado $\left(23^{\circ} 14^{\prime} 28^{\prime \prime} \mathrm{S}\right.$ and $\left.51^{\circ} 22^{\prime} 20^{\prime \prime} \mathrm{W}\right)$, Horto Florestal of the State University of Londrina (23 $19^{\prime} 45^{\prime \prime} \mathrm{S}$ and $\left.51^{\circ} 12^{\prime} 25^{\prime \prime} \mathrm{W}\right)$, Sítio Santana $\left(23^{\circ} 20^{\prime} 7^{\prime \prime} \mathrm{S}\right.$ and $\left.51^{\circ} 16^{\prime} 44^{\prime \prime} \mathrm{W}\right)$ and Parque Municipal Histórico of Cambé (23 17' 56" S and $5^{\circ} 16$ ' 43" W) (see Figure 1). The geographic coordinates were obtained through the Google Earth Pro program, 4.2.0180.1134 version.

The maximum distance between the studied areas is of $20 \mathrm{~km}$ and the minimum is $4.1 \mathrm{~km}$. Since the sites are close, they have similar characteristics in relation to climate

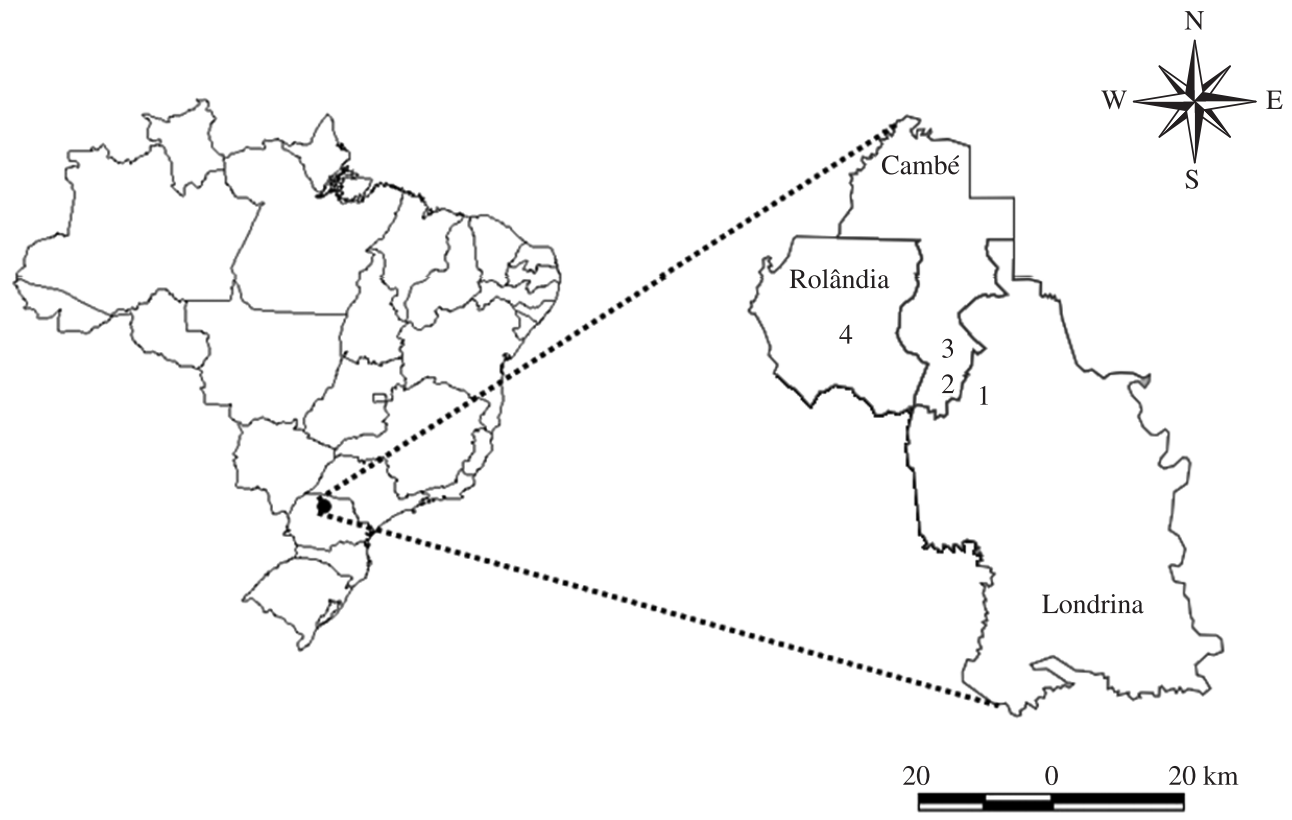

Figure 1. Location of forest fragments in northern Paraná (1. Sítio Cazado, 2. Horto Florestal of the State University of Londrina, 3. Sítio Santana, 4. Parque Municipal Histórico of Cambé). 
and vegetation. According to Köppen's classification, the climate is humid subtropical and all fragments are remnants of semideciduous forest, which has highly diversified tree flora, compared to other forest types (Gusson, 2007).

\subsection{Methodology}

A monthly sampling was performed for each fragment, for the period of July 2008 to June 2009. We used eight nets for collection, which remained open during the first four hours of the night, totalling 192 hours over a year of study. The nets were set on trails and examined at intervals of 15 minutes (Reis, 1984), to avoid the stress of captive animals and prevent damage to the nets, caused by them.

The captured animals were marked and identified in the field with the aid of keys produced by Vizotto and Taddei (1973), Reis et al. (1993). The marking occurred from October 2008 to March 2009 and was accomplished through the use of anodised metal rings of four different colours, each colour corresponding to a fragment, to monitor possible displacements. Three sizes were used $(2.5 \mathrm{~mm}$, $4 \mathrm{~mm}$ and $6 \mathrm{~mm}$ in diameter) to cover bats considered small, medium and large.

\section{Results}

Of the four hundred and ninety-five individuals captured, one hundred and fifty were banded and since the first capture, four displacements were recorded (Table 1). After five months of collecting and marking, one Carollia perspicillata (Linnaeus, 1758) was found $3 \mathrm{~km}$ from the fragment where the marking occurred (Sítio Santana), being near the other remaining forest area (Parque Municipal) inserted in the studied area. The second displacement was recorded after one year and 10 months and one Artibeus lituratus (Olfers, 1818) was found at about $20 \mathrm{~km}$ (at the State University of Londrina) from the marking site (Sitio Cazado). The third displacement happened two years after the first collection, where another A. lituratus was located at about $20 \mathrm{~km}$ (also at the State University of Londrina) from the marking site (Sitio Cazado). And finally, a fourth movement was recorded after two years and two months, and one Platyrrhinus lineatus (E. Geoffroy, 1810) was captured at about $20 \mathrm{~km}$ (State University of Londrina) from the marking fragment (Sítio Cazado) (see Figure 2). For the time between marking and recapture, Gardner et al. (1991) estimated the life time of Artibeus fimbriatus Gray, 1838 in 4.5 years and Wilson and Tyson (1970) obtained an average of 7 years. Corroborating with these studies, we note here that the species mentioned have great potential for survival, which provides a better use of the landscape.

\section{Discussion}

If individuals of a population move between patches of certain habitats, establishing a connection, there is the formation of a metapopulation. Bats, like mammals, are evolutionarily superior when compared to other taxons. So they have three basic activities: feeding, reproduction and protection (Branco and Rocha, 1980). As they move around over large distances, and as they are not monogamous, they are obviously induced by hormones to mate with females of

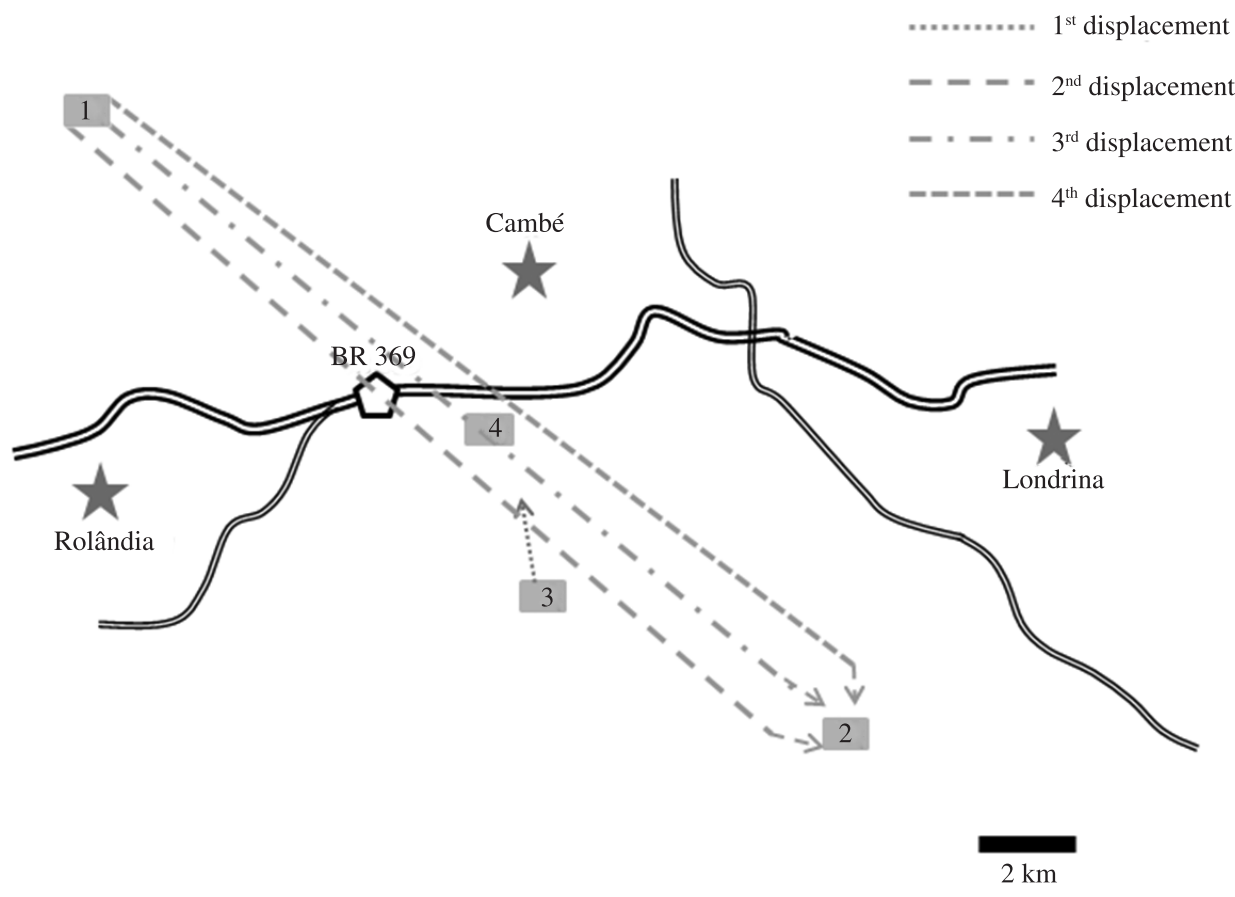

Figure 2. Scheme of displacements in the studied landscape (1. Sítio Cazado, 2. Horto Florestal of the State University of Londrina, 3. Sítio Santana, 4. Parque Municipal Histórico of Cambé) and displacements recorded in the region. 
other distant fragments. Therefore, populations of bats have the ability to increase genetic diversity in metapopulation, provided by the displacements between the forest fragments. Species that behave like this are not as vulnerable to disappearance, as those with little displacement. That is, this is simply the practice of their second strongest instinct after feeding, i.e. reproduction, through crosses between individuals from different populations. Still, in relation to mating behaviour, polygamy is seen as a potentially important factor for the effective size of a population and gene flow (Salgueiro, 2007).

Costa et al. (2006) reported the displacement of a male Artibeus fimbriatus in the state of Rio de Janeiro, which was recaptured 20 days after the first capture, at a distance of $21.7 \mathrm{~km}$, with descent testicles, which indicates the maintenance of gene flow between mainland and islands in the southern state. This fact clearly suggests the establishment of a metapopulation.

Bianconi et al. (2006) recaptured, after banded 653 bats of seven species, 54 individuals of six species in three different forest fragments in southern Brazil, and C. perspicillata and A. lituratus were recaptured more frequently, suggesting high mobility, showing, as the authors say, that the species are spatially arranged to use the landscape as a whole.

Esberárd (pers. obs.) cited a displacement of $71 \mathrm{~km}$ of an individual of the species A. lituratus and even small movements of $C$. perspicillata, Glossophaga soricina (Pallas, 1766), Anoura caudifer (E. Geoffroy, 1818), A. fimbriatus,
Artibeus obscurus Schinz, 1821 and P. lineatus. When the bats move, they promote an increase in reproductive success, which could be in decline by the reduction of their populations generated by fragmentation of habitats. Consequently the variability increases within populations that are interrelated and it is known that genetic variability is vital for the maintenance of populations (Frankham et al., 2002).

Large displacements of Molossidae have always been clear (Altringham, 1996), forming large colonies, where sometimes millions of individuals live, which surely exchange genes. This knowledge is also essential for future studies with phylostomidae families and probably other families that are in the south and the rest of Brazil. That is, you need to know that these individuals can exchange genes between populations, living as metapopulations and trying to survive, despite the resistance imposed by the destruction and loss of habitat, since many regions show mosaics only (Begon et al., 2007). Some areas have small populations or are inhabited because individuals fail to disperse to reach them (Andrewartha and Birch, 1954). However the bats fly and several species of bats, especially of the genera Artibeus, Uroderma, Carollia and Phyllostomus probably treat the modified habitats as homogeneous compared to frequent records of their environmental plasticity (Fenton et al., 1992; Medellin et al., 2000; Sazima et al., 1994; Zortéa and Chiarello, 1994; Pedro et al., 1995; Reis and Muller, 1995; Reis et al., 2003).

Table 1. Species recorded, frequency of occurrence and number of marked individuals.

\begin{tabular}{|c|c|c|c|c|c|c|c|c|c|c|}
\hline \multirow[t]{2}{*}{ Species recorded } & \multicolumn{2}{|c|}{$\begin{array}{c}\text { Horto } \\
\text { Florestal }\end{array}$} & \multicolumn{2}{|c|}{$\begin{array}{c}\text { Parque } \\
\text { Municipal }\end{array}$} & \multicolumn{2}{|c|}{$\begin{array}{c}\text { Sítio } \\
\text { Santana } \\
\end{array}$} & \multicolumn{2}{|c|}{$\begin{array}{c}\text { Sitio } \\
\text { Cazado }\end{array}$} & \multicolumn{2}{|c|}{$\begin{array}{c}\text { Marked } \\
\text { individuals }\end{array}$} \\
\hline & $\mathbf{N}$ & $\%$ & $\mathbf{N}$ & $\%$ & $\mathbf{N}$ & $\%$ & $\mathbf{N}$ & $\%$ & $\mathbf{N}$ & $\%$ \\
\hline \multicolumn{11}{|l|}{ Family Phyllostomidae } \\
\hline \multicolumn{11}{|l|}{ Subfamily Desmodontinae } \\
\hline Desmodus rotundus (E. Geoffroy, 1810) & & & & & & & 2 & 0.9 & & \\
\hline \multicolumn{11}{|l|}{ Subfamily Glossophaginae } \\
\hline Glossophaga soricina (Pallas, 1766) & 1 & 0.73 & & & & & & & & \\
\hline \multicolumn{11}{|l|}{ Subfamily Carollinae } \\
\hline Carollia perspicillata (Linnaeus, 1758) & 10 & 7.35 & 12 & 13.6 & 15 & 30.6 & 77 & 35 & 21 & 14 \\
\hline \multicolumn{11}{|l|}{ Subfamily Phyllostominae } \\
\hline Phyllostomus hastatus (Pallas, 1767) & 1 & 0.73 & & & & & & & & \\
\hline \multicolumn{11}{|l|}{ Subfamily Sternodermatinae } \\
\hline Artibeus lituratus (Olfers, 1818) & 43 & 31.6 & 30 & 34.1 & 16 & 32.7 & 29 & 13 & 47 & 31.3 \\
\hline Artibeus fimbriatus Gray, 1838 & 1 & 0.73 & 5 & 5.68 & & & 2 & 0.9 & 5 & 3.3 \\
\hline Artibeus planirostris (Spix, 1823) & & & & & & & 5 & 2.3 & 2 & 1.3 \\
\hline Platyrrhinus lineatus (E. Geoffroy, 1810) & & & & & & & 8 & 3.6 & 4 & 2.7 \\
\hline Sturnira lilium (E. Geoffroy, 1810) & 73 & 53.7 & 36 & 40.9 & 16 & 32.7 & 75 & 34 & 61 & 40.7 \\
\hline Vampyressa pusilla (Wagner, 1843) & 2 & 1.48 & & & & & & & & \\
\hline \multicolumn{11}{|l|}{ Family Vespertilionidae } \\
\hline \multicolumn{11}{|l|}{ Subfamily Vespertilionae } \\
\hline Myotis nigricans (Schinz, 1821) & 5 & 3.68 & 5 & 5.68 & 2 & 4 & 24 & 11 & 10 & 6.7 \\
\hline Total & 136 & 100 & 88 & 100 & 49 & 100 & 222 & 100 & 150 & 100 \\
\hline
\end{tabular}


It is obvious, therefore, the fact that the bats were inserted within the context of metapopulation. For migratoty vespertilionids and Molossidae, insertion is more evident, since they have narrow and elongated wings, which provide long flights. Now phyllostomids must also be addressed, cited in the course of the text, which exploit large areas and different fragments in a landscape with patches of vegetation.

\section{References}

ALTRINGHAM, JD., 1996. Bats, biology and Behavior. Oxford: Oxford University Press. 262 p.

ANDREWARTHA, HG. and BIRCH, LC., 1954. The distribution and abundance of animals. Chicago: Univesrsity Chicago Press. 782 p.

BEGON, M., TOWNSEND, CR. and HARPER, JL., 2007. Ecologia de indivíduos e ecossistemas. 4th ed. Porto Alegre: Artmed Editora S/A. 740 p.

BIANCONI, G., MIKICH, SB. and PEDRO, WA., 2006. Movements of bats (Mammalia, Chiroptera) in Atlantic Forest remnants in southern Brazil. Revista Brasileira de Zoologia, vol. 23, n. 4, p. 1199-1206. http://dx.doi.org/10.1590/S0101-81752006000400030

BRANCO, SM. and ROCHA, AA., 1980. Ecologia: educação ambiental, ciências do ambiente para universitários. São Paulo: CETESB. 80 p.

COSTA, LM., PRATA, AFD., MORAES, D., CONDE, CFV., JORDÃO-NOGUEIRA, T. and ESBÉRARD, CEL., 2006. Deslocamento de Artibeus fimbriatus sobre o mar. Chiroptera Neotropical, vol. 12, n. 2, p. 289-290.

FENTON, MB., ACHARYA, L., AUDET, D., HICKEY, MBC., MERRIMAN, C., OBRIST, MK. and SYME, DM., 1992. Phyllostomid bats (Chiroptera: Phyllostomidae) as indicators of habitat disruption in the Neotropics. Biotropica, vol. 24, p. 440-446. http://dx.doi.org/10.2307/2388615

FLEMING, TH. and EBY, P., 2003. Ecology of bat migration. In KUNZ, TH. and FENTON, MB. Bat Ecology. Chicago: University of Chicago Press. p. 156-208.

FRANKHAM, R., BALLOU, JD. and BRISCOE, DA., 2002. Introduction to Conservation Genetics. Cambridge: Cambridge University Press. 617 p.

GARDNER, AL., HANDLEY, JR. and WILSON, DE., 1991. Survival and Relative Abundance. In HANDLEY, JR., WILSON, DE. and GARDNER, AJ. Demography and Natural History of the Common Fruit Bat, Artibeus jamaicensis, on Barro Colorado Island, Panamá. Smithsonian Contributions to Zoology. p. 53-75.

GUSSON, AE., 2007. Composição florística e estrutura fitossociológica da comunidade arbustivo-arbórea de uma floresta estacional semidecidual no município de Ipiaçu. Uberlândia: Universidade Federal de Uberlândia. 40 p. Monografia de Graduação em Ciências Biológicas-Bacharelado.

LEVINS, R., 1970. Extinction. In GESTERNHABER, M. Some mathematical problems in Biology. Providence, Rhode Island: American Mathematical Society. p. 77-107.

MACARTHUR, RH. and WILSON, EO., 1967. The theory of Island Biogeography. Princeton: Princeton University Press. 203 p.

MEDELLIN, RA., EQUIHUA, M. and AMIN, MA., 2000. Bat diversity and abundance of the indicators of disturbance in Neotropical rainforests. Conservation Biology, vol. 14, p. 1666-1675. http:// dx.doi.org/10.1046/j.1523-1739.2000.99068.x

ODUM, EP. and BARRETT, GW., 2007. Fundamentos de Ecologia. 5th ed. São Paulo: Thomson Learning.

PAGLIA, AP., FERNANDEZ, FAS., DE MARCO-JR, P., 2006. Efeitos da Fragmentação de Habitats: quantas espécies, quantas populações, quantos indivíduos e serão eles suficientes? In ROCHA, CFD., BERGALLO, HG., VAN SLUYS, M. and ALVES, MAS. Biologia da Conservação: Essências. São Carlos: RIMA Editora. p. 281-316.

PEDRO, WA., GERALES, MP., LOPEZ, GG. and ALHO, CJR., 1995. Fragmentação de habitat e a estrutura de uma taxocenose de morcegos em São Paulo (Brasil). Chiroptera Neotropical, vol. 1, n. 1, p. 4-6.

PIRES, AS., RAVETTA, A., MELLO, MAR., RUIZ, CR., SETZ, EZF., 2003. Mamíferos. In RAMBALDI, D. and OLIVEIRA, D. Fragmentação de ecossistemas: Causas, efeitos sobre a biodiversidade e recomendações de políticas públicas. Brasília: Ministério do Meio Ambiente, Secretaria de Biodiversidade e Florestas. p. 125-152.

PRIMACK, RB., 1993. Essentials of Conservation Biology. Sunderland: Sinauer Associates Inc. 564 p.

REIS, NR., 1984. Estrutura de comunidade de morcegos da região de Manaus, Amazonas. Revista Brasileira de Biologia. Brazilian Journal of Biology, vol. 44, no. 3, p. 247-254.

REIS, NR. and MULLER, MF., 1995. Bat Diversity of forest and open areas in a subtropical region of South Brasil. Revista de Ecologia Austral, v. 5, p. 31-36.

REIS, NR., MULLER, MF., SOARES, ES., PERACCHI, AL., 1993. Lista e Chave de Quirópteros do Parque Estadual Mata do Godoy e Arredores, Londrina, Pr. Semina: Ciencias biologicas e da saude, vol. 14 , no. 2 , p. $120-126$.

REIS, NR., PERACCHI, AL. and LIMA, IP., 2003. Morcegos da bacia do Rio Tibagi. In: MEDRI, ME., BIANCHINI, E., SHIBATTA, AO. and PIMENTA, JA. A bacia do rio Tibagi. Londrina, os Editores. p. 251-270.

RICKLEFS, RE., 1993. Economia da Natureza. 5th ed. Rio de Janeiro: Editora Guanabara Koogan. 502 p.

SALGUEIRO, PIR., 2007. Genetic Structure and Gene Flow of fragmented bat populations: consequences for conservation. Lisboa: Universidade de Lisboa. 186 p. Tese de Doutorado.

SAZIMA, I., FISCHER, WA., SAZIMA, M. and FISCHER, EA., 1994. The fruit bat Artibeus lituratus as a forest and city dweller. Ciência e Cultura, vol. 46, p. 164-168.

STOCKWELL, CA, HENDRY, AP. and KINNISON, T., 2003. Contemporary evolution meets conservation biology. Trends in Ecology and Evolution, vol. 18, p. 94-101. http://dx.doi.org/10.1016/ S0169-5347(02)00044-7

VIZOTTO, LD. and TADDEI, VA., 1973. Chave para determinação de quirópteros brasileiros. Boletim de Ciências. Faculdade de Filosofia, Ciências e Letras São José do Rio Preto, vol. 1, p. 1-72.

WILSON, DE. and TYSON, EL., 1970. Longevity Records for Artibeus jamaicensis and Myotis nigricans. Journal Of Mammalogy, vol. 51, n. 1, p. 203. http://dx.doi.org/10.2307/1378570

ZORTÉA, M. and CHIARELLO, AG., 1994. Observations on the big fruit-eating bat, Artibeus lituratus, in an Urban Reserve of South-east Brazil. Mammalia, vol. 58, n. 4, p. 665-670. 
